\title{
Genetic modulation of soluble $A \beta$ rescues cognitive and synaptic impairment in a mouse model of $A D$
}

\author{
Stephanie Fowler ${ }^{1}$, Angie Chiang ${ }^{1}$, Ricky Savjani ${ }^{1,2}$, Megan Larson ${ }^{3,4}$, Dorothy Schuler ${ }^{5}$, John Cirrito ${ }^{5}$, \\ Sylvain Lesne $e^{3,4}$, Joanna Jankowsky ${ }^{1,6^{*}}$
}

From Molecular Neurodegeneration: Basic biology and disease pathways

Cannes, France. 10-12 September 2013

\section{Background}

There has been a longstanding debate on whether amyloid plaques are pathogenic by causing physical damage to surrounding tissue or protective by sequestering more toxic soluble forms of amyloid $\beta$ (A $\beta$ ) peptide. Numerous studies in mouse models have documented a complex relationship between soluble $A \beta$, deposited aggregates, and cognitive decline, but few experimental systems have been capable of dissecting how each form of the peptide contributes to the progressive memory deficits of Alzheimer's disease. Here we use a controllable transgenic model expressing a mutant form of amyloid precursor protein (APP) to distinguish the impact of APP and soluble A $\beta$ from that of deposited amyloid on cognitive function and synaptic structure.

\section{Materials and methods}

We created a transgenic model in which the tetracycline transactivator drives expression of APPswe/ind in neurons throughout the forebrain. After 6 months of transgene expression when amyloid burden reached approximately $10 \%$, we placed half of the mice on doxycycline to suppress further production of transgenic APP and human A $\beta$. All animals were then tested for cognitive function using the Morris water maze, radial arm water maze, and fear conditioning. Once testing was complete, we harvested the mice to examine amyloid pathology, synapse density, oligomeric $A \beta$, and synaptic protein levels.

\section{Results}

Doxycycline treatment suppressed expression of transgenic APP by $>90 \%$ and diminished production of human $\mathrm{A} \beta$ by $70 \%$ while leaving pre-existing amyloid deposits intact. Remarkably, this treatment restored cognitive performance to the level of healthy controls in all of the behavioral tasks examined. Cognitive improvement coincided with reduced levels of synaptotoxic $A \beta$ oligomers, greater synaptic density surrounding amyloid plaques, and increased expression of pre- and post-synaptic markers. To demonstrate that recovery was due to reduction of $A \beta$ and not simply suppression of APP, we treated a second cohort of mice with the $\gamma$-secretase inhibitor LY411575 and observed similar although somewhat less complete recovery in both Morris water maze and synaptic markers. Finally, transgene suppression normalized activation of the actin-depolymerizing protein cofilin in a PAK-independent manner, suggesting that $\mathrm{APP} / \mathrm{oA} \beta$ may alter synaptic structure through the opposing Rho/ROCK pathway.

\section{Conclusions}

These findings indicate that transient forms of APP and $\mathrm{A} \beta$ underlie much of the behavioral and synaptic recovery observed in this model. Our work further suggests that residual amyloid deposits need not be removed for successful intervention at this early stage of disease.

\footnotetext{
Acknowledgments

This work was funded by NIH DP2 OD001734, T32 AG000183, R00 AG031293, R01 NS033249 and by a gift from the Robert and Rene Belfer Family Foundation.
}

${ }^{1}$ Neuroscience, Baylor College of Medicine, Houston, TX, USA

Full list of author information is available at the end of the article

(c) 2013 Fowler et al; licensee BioMed Central Ltd. This is an Open Access article distributed under the terms of the Creative Commons Attribution License (http://creativecommons.org/licenses/by/2.0), which permits unrestricted use, distribution, and reproduction in any medium, provided the original work is properly cited. 


\section{Authors' details}

${ }^{1}$ Neuroscience, Baylor College of Medicine, Houston, TX, USA. ${ }^{2}$ Texas A\&M Health Science Center, College Station, TX, USA. ${ }^{3}$ Neuroscience, University of Minnesota, Minneapolis, MN, USA. ${ }^{4}$ N. Bud Grossman Center for Memory Research and Care, Institute for Translational Neuroscience, University of Minnesota, Minneapolis, MN, USA. ${ }^{5}$ Neurology, Washington University School of Medicine, St. Louis, MO, USA. 'Neurology, Neurosurgery, and Huffington

Center on Aging, Baylor College of Medicine, Houston, TX, USA.

Published: 13 September 2013

doi:10.1186/1750-1326-8-S1-030

Cite this article as: Fowler et al: Genetic modulation of soluble $A \beta$

rescues cognitive and synaptic impairment in a mouse model of AD.

Molecular Neurodegeneration 2013 8(Suppl 1):O30.

Submit your next manuscript to BioMed Central and take full advantage of:

- Convenient online submission

- Thorough peer review

- No space constraints or color figure charges

- Immediate publication on acceptance

- Inclusion in PubMed, CAS, Scopus and Google Scholar

- Research which is freely available for redistribution

Submit your manuscript at www.biomedcentral.com/submit 